Portland State University

PDXScholar

1989

\title{
An estimation of relatedness within two Oregon populations using isonymy analysis
}

Maria Michalczyk

Portland State University

Follow this and additional works at: https://pdxscholar.library.pdx.edu/open_access_etds

Part of the Demography, Population, and Ecology Commons, and the Social and Cultural Anthropology Commons

Let us know how access to this document benefits you.

\section{Recommended Citation}

Michalczyk, Maria, "An estimation of relatedness within two Oregon populations using isonymy analysis" (1989). Dissertations and Theses. Paper 3907.

https://doi.org/10.15760/etd.5791

This Thesis is brought to you for free and open access. It has been accepted for inclusion in Dissertations and Theses by an authorized administrator of PDXScholar. Please contact us if we can make this document more accessible: pdxscholar@pdx.edu. 
AN ABSTRACT OF THE THESIS OF Maria Michalczyk for the Master of Arts in Anthropology presented May 3, 1989.

Title: An Estimation of Relatedness Within Two oregon Populations Using Isonymy Analysis.

APPROVED BY THE MEMBERS OF THE THESIS COMMITTEE.

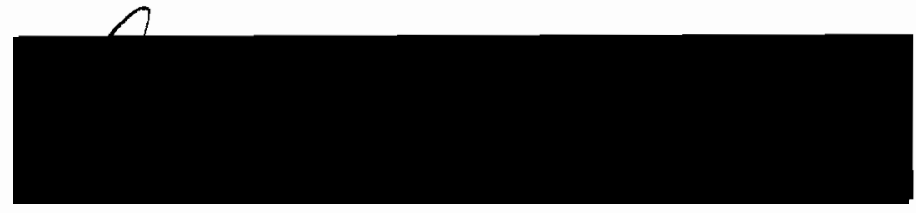

Marc R. Feldesman, Chair

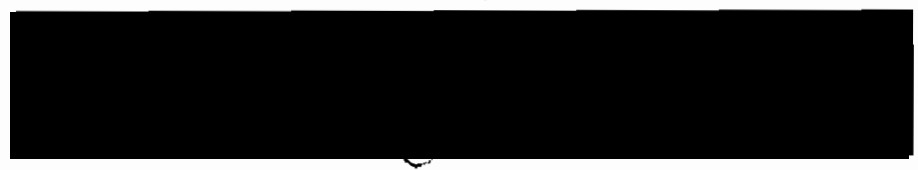

Patricia Kramer
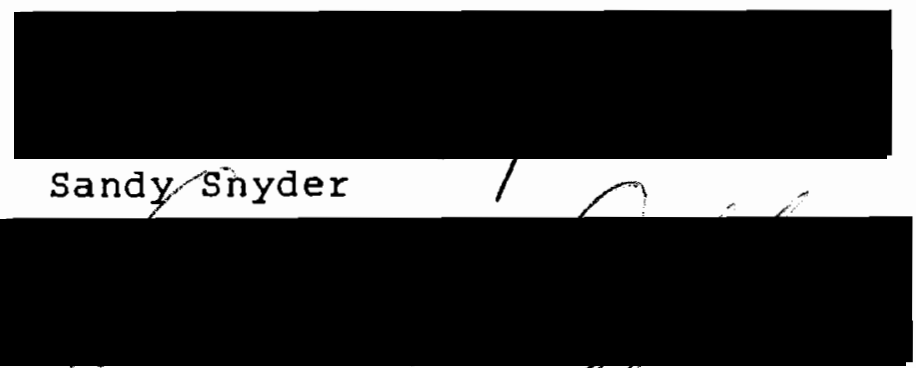

Deborah A. Duffield

The study of human relatedness has long interested the population geneticist. One technique for the estimation of population relatedness is the use of isonymy analysis. The isonymy inbreeding coefficient is analogous to wright's inbreeding coefficient $\mathbf{F}$. Isonomy analysis can yield comparable results to population studies done by other means 
such as pedigree analysis, serological studies, and anthropometric analysis.

The data used for this study was obtained from marriage records and telephone directories. Same last name marriages were observed for legitimacy and recorded when verified.

A pool of last names were drawn from the marriage records. This list was used to compare and tally like names found in telephone directories for corresponding years and localities.

Two Oregon counties (Multnomah and Lincoln) were studied using this method as well as two time periods (years). Multnomah County has the largest population base in the state and Lincoln county is relatively rural. The years studied were 1946 and 1986 . The year 1946 was chosen to determine if War World II had had any impact on population relatedness and 1986 was chosen because it was the most recent year for which a complete data base was available.

The largest inbreeding coefficient found was in Lincoln County $1986(F=.001496)$. The second largest inbreeding coefficient was in Multnomah County $1946(F=.0007877)$, followed by Lincoln County $1946(F=.0001981)$ and finally Multnomah County $1986(F=.00009202)$. It had been expected that rural Lincoln County would have the largest inbreeding coefficient (relatedness/inbreeding): these expectations were partially met. The relatively large 
have been uniquely inflated due to wartime immigration into the county.

The number of isonymic marriages observed for each county and each year were very small. This may be due to the small sample size in Lincoln County as well as the fact that isonymity is a relatively uncommon phenomenon. 
AN ESTIMATION OF RELATEDNESS WITHIN TWO

OREGON POPULATIONS USING ISONYMY ANALYSIS

by

MARIA MICHALCZYK

A thesis submitted in partial fulfillment of the requirements for the degree of

\author{
MASTER OF ARTS \\ in \\ ANTHROPOLOGY
}

Portland state University

1989 
TO THE OFFICE OF GRADUATE STUDIES:

The members of the Committee approve the thesis of Maria Michalczyk presented May 3, 1989.

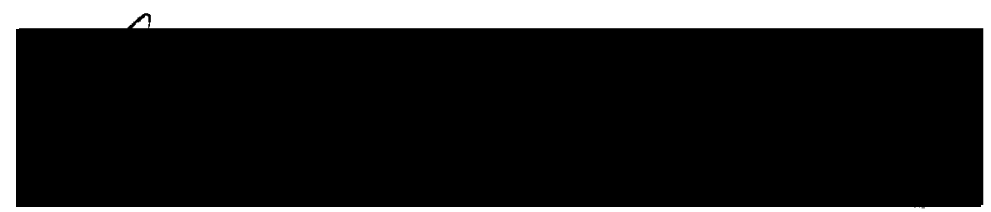

Marc R. Feldesman, Chair

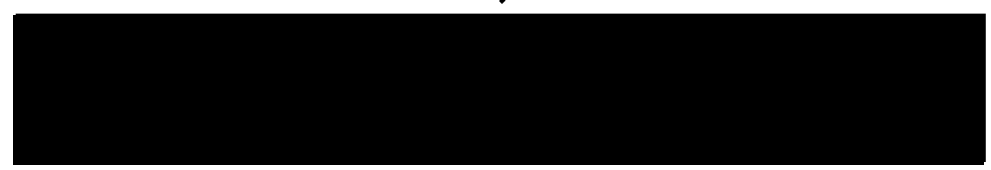

Patricia Kramer

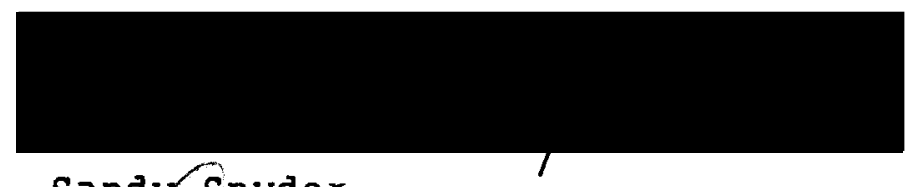

Sandy Snyder

Deborah A. Duffield

\section{APPROYED :}

Marc R. Feldesman, Chairman, Anthropology

C. William Savery, Vicé Provost for Graduate studies 


\section{ACKNOWLEDGEMENTS}

The completion of any major undertaking cannot be realized without the generosity, kindness and knowledge of many individuals. This thesis is a culmination of efforts that would have not been possible without the steady hand of guidance afforded by a concert of supportive individuals. Most importantly, this project represents a guided tour through academic growth, for which I extend my warmest thanks to my advisor, Marc Feldesman, for his help during the past three years.

I would also like to thank those who took time out of their busy lives to help. Dr. Gabriel Lasker answered all my letters and was so willing to help. Patty kramer met with me countless times to discuss various issues regarding isonymy analysis. Nell Conley was very kind to provide me with first hand knowledge about the early days of telephone service in the state of Oregon. The staff of Multnomah and Lincoln County records departments provided invaluable assistance and patience during my seemingly endless days reviewing literally thousands of marital records. Thanks go as well to susan Fillmore, R.N., my employer, who without her understanding and flexibility I could have never finished. And finally, 
love, kisses, and chiggers for Robert Vandiver: the man I shall marry soon, who has been patient, understanding, tolerant and has helped me in countless ways. 
TABLE OF CONTENTS

PAGE

ACKNOWLEDGEMENTS .................... i i i

LIST OF TABLES...................... vi

LIST OF FIGURES ...................... vii

CHAPTER

I INTRODUCTION $\ldots \ldots \ldots \ldots \ldots \ldots \ldots \ldots \ldots \ldots$

I I REVIEW OF THE LITERATURE $\ldots \ldots \ldots \ldots \ldots \ldots$

I I METHODS $\ldots \ldots \ldots \ldots \ldots \ldots \ldots \ldots \ldots \ldots \ldots$

Isonymy Analysis............... 8

Marriage Records .............. 12

Name Frequency $\ldots \ldots \ldots \ldots \ldots \ldots \ldots$

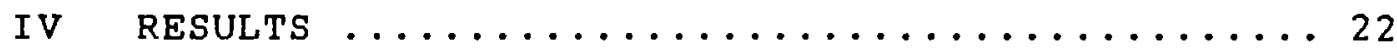

Marriage Results.............. 22

Inbreeding Coefficients Results....... 25

surnames................... 29

$\mathrm{V}$ DISCUSSION AND CONCLUSIONS $\ldots \ldots \ldots \ldots \ldots \ldots$

BIBLIOGRAPHY $\ldots \ldots \ldots \ldots \ldots \ldots \ldots \ldots \ldots \ldots \ldots \ldots \ldots \ldots$ 


\section{LIST OF TABLES}

TABLE

PAGE

I Inbreeding Coefficients for Isonymy Analysis ..10

I Telephone Directory Estimates for Each Year

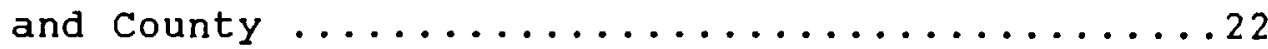

II The Total Number of Marriages, Sample Sizes and Populations for Each Year and County .....24

IV The total Number of Expected and Observed

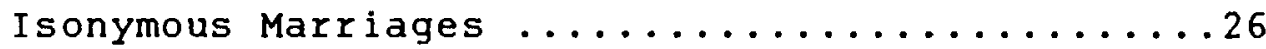

V Isonymy coefficients for Lincoln and Multnomah Counties for both 1946 and $1986 \ldots \ldots \ldots \ldots$

VI The Total Number of Unique Names and Percentage of Unique Names For the Marriage Records of Multnomah and Lincoln County ................... VI I Comparison of Inbreeding Coefficients .......39 


\section{LIST OF FIGURES}

1. Map of Oregon--Multnomah and Lincoln Counties....42 


\section{CHAPTER I}

\section{INTRODUCTION}

The study of human population relatedness has long interested the population geneticist. This study can allow a better understanding of population genetic structure and consequently evolution.

Population relatedness can be estimated in many ways: pedigree analysis; anthropometric measures; serological testing; marital distances; and isonymy analysis. Typically, small contained populations have been investigated to understand the dynamics of human evolution.

Western industrialized populations are relatively large and present the researcher with a multitude of problems that make analysis complex. For example, the mobile nature of a population makes identification and determination of genetic relationships difficult.

A large, western, industrialized society is presumed to be subject to a higher degree of immigration and emmigration. Such a population is also presumed to be subject to a decrease in consanguinity amongst the members of the community. 
Many researchers assert that smaller populations exhibit a greater amount of inbreeding than larger populations. My goal is to compare the differences in relatedness between a small and a large population to verify this assertion. Furthermore, I would like to know if relatedness has changed in a forty year period in both populations. Public records (in this case marriage records and telephone directories) can provide the raw data for this study.

In my research I used isonymny (marriage between individuals with the same surname) analysis to estimate the degree of relatedness within two oregon populations. Isonymy analysis estimates the degree of inbreeding via a statistical analysis analogous to wright's inbreeding coefficient: F (see chapter II for a more detailed explanation of this procedure). Crow and Mange (1965) first used the use of the isonymny inbreeding coeffcient.

Similar to Wright's $F$, the isonymny inbreeding coefficient has a random and nonrandom component. In my study, I determined these components by analyzing sampled surnames in both populations. Surnames, as described by crow (1980: 1), "...are inherited as if it were determined by a gene linked to the $Y$ chromosone and expressed in all the children of the gene's carrier." Isonymy analysis assumes that surnames are inherited patrilineally. This type of analysis does not take into 
account the innumerable variations of surnames and/or cultural idiosyncrasies.

Bhatia and wilson (1981) point out that Wright's $F$ and the isonymny inbreeding coefficient are different, concluding that, the inbreeding definitions of these two coefficients may be measuring different components of population inbreeding. This point is made so that one understands that the two coefficients may be parallel but not identical.

The interpretation of results from this type of analysis rests on three assumptions (Lasker 1985: 23) :

(1) surnames are monophyletic and sharing a surname means sharing an ancestor from whom it was derived;

(2) that each degree of relationship matings along the male line are proportional to the number of $k$ inds of lines; and (3) the two sexes are equally represented among migrants.

Lasker notes that these assumptions are typically satisfied only partially (Lasker 1985:23). Violations of these assumptions will be addressed in Chapter $v$.

Although isonymy analysis has limitations, it is an economical and time saving research tool. This method in particular is useful for the investigation of relatedness in large populations. It is also true that in many cases this may be the only way to roughly estimate relatedness when data are otherwise insufficient. 
Migration phenomena, geographic distances, population structures and population ancestry have all been estimated by isonymic associations. 


\section{CHAP TER I I}

\section{REVIEW OF THE LITERATURE}

Since the introduction of the isonymy inbreeding coefficient in 1965 by Crow and Mange, many studies have used this mathematical tool to estimate relatedness among populations (Allen 1988; Barrai et al. 1987; Clegg 1986; Crow and Mange 1965; Fuster 1986; Gottieb 1983; Hurd 1983; Jorde and Morgan 1987; Lafranchi et al. 1988; Lasker 1977; Lasker 1988; Mascie-Taylor et al. 1987; Relethford and Jaquish 1988; Smith and Hudson 1984; Yasuda 1983 and Yasuda and Furusho 1971). Genetic relationships of large, small and isolated populations have been examined by surname estimations. Additionally, researchers have used isonymy inbreeding coefficients to understand genetic relationships of historical populations.

Isonymic associations go back to 1875, when G. Darwin estimated inbreeding distances of cousin marriages by surname analysis (Lasker 1985). Further investigation was done by Kamizaki in 1954 (Yasuda 1983) when he calculated the probability of random and nonrandom isonymy among Japanese populations. Crow and Mange (1965) popularized isonymy analysis by introducing the isonymy inbreeding coefficient (a modified version of Wright's inbreeding 
coefficient) to estimate genetic relationships within populations. Lasker (1977) modified the isonymy inbreeding coefficient to measure genetic relationships between populations.

Lasker and his associates have done numerous isonymy studies $(1968,1969,1972,1977,1978,1979,1983,1985$, 1986, 1988). He has used this type of analysis to measure genetic relationships between populations; measure migration between communities and to measure the amount of genetic isolation of populations due to consanguinity or geographic isolation.

In order to evaluate and provide a control for isonymy analysis, comparisons have been done with pedigree analysis. Yasuda and Morton (1967) concluded that pedigree and isonymy analysis provided equivalent results. However, Roberts and Roberts (1983) and Lasker (1985) concluded that isonymy measurements overestimated genetic relationships.

The reasons for the disparity seen between pedigree and isonymy analysis are not certain. Factors influencing the differences may be sample size (Roberts and Roberts 1983), immigration (Crow 1980), polyphyletic origins of names (Crow 1980), non-random involvement of the sexes in consanguineous marriages (Crow 1980), truncated pedigrees (Rogers 1987) and measurement of more remote ancestry via surnames than in pedigrees because of missed information through interviews (Crow 1980, 1983; Lasker 1985). 
Despite these problems with isonymy analysis, the conclusions are positive towards using this method to estimate genetic relationships within and between populations. 


\section{CHAPTER II I}

\section{METHODS}

\section{SONYMY ANALYSIS}

Utilizing isonymy analysis, I estimated the levels of consanguinity for Lincoln and Multnomah Counties for the years 1946 and 1986 (see Figure 1 for the counties in Oregon). I chose 1946 to determine the effects of World War II on mating structures as compared to a peace time environment in 1986. I selected 1986 because it represents the most recent year for which complete data are available.

The use of isonymy analysis can present unique methodological problems because of the variations of names that occur through time. Weiss et al. (1983) suggest that "mutations" in names (analogous to allele mutations) can seriously affect the results of isonymy calculations. The following are a few of the problems associated with surname use (some of which can create violations of the assumptions used in isonymy analysis):

1. Spellings of names can change over time (Weiss et al. 1983).

2. Misspellings of names can occur in public documents (Weiss et al. 1983).

3. The difficulty in determining whether similarly 
spelled last names are from the same origin. Treating similar sounding names as distinctive, unique names may inflate the isonymy estimate (Weiss 1983).

4. The inability to determine genetic relationships when illegitimacy, abandonment and adoption have occurred (Crow and Mange 1965).

5. The difficulty in determining the inconsistencies of name giving (Crow and Mange 1965).

The above factors must be considered before accepting the results of isonymy analysis.

I estimated consanguinity of the two populations using the isonymy inbreeding coefficient (F) defined by Crow and Mange (1965). This inbreeding coefficient is comprised of two mating possibilities (see TABLE I): the random (Fr) and the nonrandom (Fn).

The random isonymy coefficient in part is an expression of probability: the probability that two randomly chosen persons will share the same last name. The nonrandom portion of the inbreeding coefficient is the amount left over from the calculated Fr caused by isonymous marriages. The sum of the proportions of individuals in a population carrying a unique name represents the random inbreeding coefficient. Once this sum has been calculated it is then divided by the constant 4. This constant as noted by Lasker (1985: 23): "... is the likelihood of a gene 
TABLE I

IABREEDIAG COEFFICIRITS FOR ISOHYT AMALISIS

$P=F+(1-F) P r$

$F \mathbf{r}=\Sigma p_{1} q_{1} / 4$

$P \mathbf{P}=\left(\mathbf{P}-\Sigma_{2} g_{1}\right)$ S(1- $\left.\operatorname{sp}_{1} q_{1}\right)$
(1)

(2)

(3)

$P_{1}=$ the proportion of males in a population with a : unique surname

$q_{1}=$ the proportion of females in a population with a unique surname

the total number of 1 sonymic marriages in a sample

$P=$ the total number of marriages in a sample 
being shared by the homologous autosomal chromosomes of an offspring of first-degree relative ..."

As seen on TABLE $I, \mathbf{P}_{\mathbf{i}}$ and $\mathbf{q}_{1}$ represent the proportion of males and females respectively who carry a unique surname. A unique surname is a specific name found within the population. For example, Smith is a common name in the United States. However, no matter how many Smiths are found for a specific study, they are still represented by that one unique name. Due to the inability to determine gender by last names in this research, $\mathbf{p}_{\mathbf{i}}$ and $\mathbf{q}_{\mathbf{i}}$ were transformed to $\mathbf{x}_{1}^{2}$ (where $\mathbf{p}_{1}$ is assumed to equal $q_{1}$, so $p_{1} * q_{1}=x_{1}^{2}$ ). By setting the $p_{1}$ and $q_{1}$ term to $x_{i}{ }^{2}$, gender can then be disregarded. Thus, $x_{1}{ }^{2}$ represents the proportion of individuals in a population with a unique name. The sum of $x_{1}^{2}$ is the total number of proportions for each unique surname, which is then divided by the constant 4.

TABLE I also demonstrates that the nonrandom inbreeding coefficient (Fn) is influenced by the percentage of isonymic marriages ( $P$ ). This coefficient is also sensitive to the expected randomness observed in a given sample. In an effort to obtain the inbreeding coefficient, I used public records that would provide the most information concerning surnames: marriage records and telephone directories. Marriage records were used to determine the number of isonymlc marriages and to create a sample of surnames for a 
given year and county. This representative sample of surnames would then be used to estimate the potential random matings that could occur in a given population. For example, the name smith would be found in the marriage record sample. This surname would then be located in the telephone directory and the total number of smiths found would be tallied. The total number of smiths would be squared and divided by the total number of telephone listings. Once the calculation was completed for all unique names from the sample, a summation was done. This summation was then divided by four.

\section{MARR I AGE RECORDS}

Marriage records can be among the most revealing sources of information available. The information provided by marriage records allows the researcher to discover numerous relationships of the bride and groom: surname; birthplace; parental names and birthplaces; age; and occupation. These collective data generally cannot be found in any other single public document, including census data and voter registration records. For this reason, I used marriage records as a source for my analysis.

The first step in determining the sample size was to obtain the total number of marriages for each county and year. The two counties maintained their marriage records differently. Therefore, the population size and subsequent 
samples reflected this variability. The marriage records for Multnomah County (1946 and 1986) were kept on microfilm. The license bureau has maintained records that reflect the number of applications per year. The term "application" refers to applications made for marriage. It does not differentiate between those who actually marry and those who do not. Due to the difficulty in determining the actual number of marriages that occurred for a given year, I chose the number documented by the bureau to determine the sample size.

The Lincoln County license department maintained no formal totals of marriage applications for 1946 and 1986. It was necessary therefore to tally the applications for both years. Unlike Multnomah County, all applications were accompanied by a certificate of marriage. The population and subsequent sample size therefore reflect this bias when compared to Multnomah County.

The Lincoln County records for 1946 were not on microfilm but rather were stored in boxes in the archives. The 1986 records were on microfilm. The original 1986 records had to be counted to obtain a total population size: since the numbering system of actual marriage numbers was difficult to determine on the microfilm reels. To obtain the marriage record sample sizes, the Handbook of sampling for Auditing and Accounting (Arkin 1974) was utilized. Once I determined the sampling size, a desired sampling 
fraction was chosen: $N / n=j$, where

$$
\begin{aligned}
& \mathbf{N}=\text { the total number of applications for a given } \\
& \mathbf{n}=\text { the chosen sample size and } \\
& j=\text { the sampling fraction. }
\end{aligned}
$$

The sampling fraction, every jth marriage application, was observed throughout the marriage list for a given year. The sampling fraction for Multnomah County 1946 was every 9 th application and for Multnomah County 1986 every 7 th application. The sampling fraction for Lincoln County in 1946 and 1986 was every 2nd application. This sampling method was chosen so that a bias would be prevented: every marriage record would have an equal chance of being sampled. The format for the applications was universal across the state. However, the format was changed between 1946 and 1986. Basically the application asked for: 1. Full name (including the maiden name for the bride only in 1986); 2 . Age; 3. Ethnic status; 4. Occupation; 5. Parents full name (or parents place of birth); 6. Present marital status (divorced, widowed or single); 7. Place of birth and 8 . Present residence.

All the information from every jth application was recorded unless one of the below conditions were present:

1. The application was illegible and/or too incomplete. 
2. An isonymyous marriage (or same last name marriage) was found.

3. No certificate of marriage accompanied the application .

4. Neither party resided in the county. If one of the parties was a resident of the county it was assumed that the couple would reside in the county of marriage. This assumption was based on the fact that the couple married in the county and thus planned to reside there.

As noted above, an isonymous/same surname marriage would interrupt the collection of every jth application. These marriages would be recorded, and then the count would be restarted from that record. Although all the same surname marriages were recorded, they were not all considered isonymous marriages. This point is important to highlight because one could mistakenly assume that a couple with the same surname was related.

One category of non-isonymous same surname marriages was the remarriage category. For example, in Multnomah County (1946) there was a preponderance of remarriages (52 couples). These couples had divorced and then remarried. This was verified by noting the divorce date and place on the marriage application was the same for both parties. Further verification of non-relatedness was identified via disslmilar parent surnames. Unlike the 1986 marriage 
applications, the 1946 form did not request the bride's maiden name, therefore, it was necessary to further investigate the record to verify an isonymous marriage. It is important to point this out since the bride typically would apply for remarriage using her ex (and future) husband's surname.

A second classification of same surname marriages that were not included as isonymous were Asians. Specifically in Multnomah County (1986) there were many Asian couples who had the same last name. Due to the low frequency of unique last names noted among many Asian groups, I disregarded Asian couples who shared the same last name.

Another potential isonymous group that I excluded were brides who applied with their "to be" married name rather than their maiden name. This was determined by the bride's previous marital status and her parents' last surnames. The determination of whether a marriage was isonymic was not always clear in the 1946 Multnomah County records. For example, one application listed both parties with the same surname. Neither applicant listed the names of their parents and both had been previously married and divorced. In this situation, it was almost impossible to determine if there was an isonymic relationship or if simply the bride had assumed the groom's surname before marriage. I decided to err on the conservative side and delete the uncertain applications rather than inflate the final results. 
Once all the data were collected they were placed on a database paradox II, a standard database program available for IBM PC's and compatible computers. The data were then sorted by separate years and counties. These lists were then alphabetized. The alphabetized lists were then sorted disregarding gender. Duplicate surnames were included. Thus, the alphabetized inventory provided an accounting of all names observed for each county and year.

\section{NAME FREQUENCY}

The third phase of this research was to determine a public record source containing a significant number of names that properly represent the entire population. There are in fact very few resources available to the public for this type of information --especially when one is examining a large multidenominational/pluralistic ethnic population. Small or confined populations have complete records if, for example, they have a certain religious affiliation. In a large population, the telephone directory is the most complete source available for a contemporary population study. Telephone directories were used to determine the random component $(F r)$ of the inbreeding coefficient: $F$. As mentioned earlier the initial sample of names was obtained from the marriage records. Once the sample was obtained, these surnames were compared and tallied to the same surnames found in the population. Thus, all names recorded 
from the marriage records were compared to the same names as found in the population. The names in the population were represented by the names found in the telephone directory. For example, the surname Baker was noted in the 1946 Lincoln county marriage records. This name was then found in the telephone directory and the number of Bakers observed was totaled. As previously mentioned no regard was given to gender but rather to the identification of the unique surname $X i$ observed in the directory. This procedure was done for each unique surname for each year and county.

All telephone directories were obtained from the Multnomah County (Portland, Oregon) library except for the 1986 Portland Directory. The format of the directories differed for each year and county: each directory listed different communities for a given year or county. In an attempt to remain consistent, I used several procedures to include as much of each county as possible.

In $1946,51.48$ of the households in the nation had telephone service in their homes (Historical statistics of the United States, 1976). The presence of home phones dramatically increased to 92.28 in 1986 (statistical Abstract of the United States, 1988).

Telephone service in 1946 was splintered: regions were serviced by independent private companies. I discovered (via personal communication with a retired Bell Company employee Conley 1988 ) that during 1946 there were well over 
Eifty companies providing service to oregon communities. some companies tended to have unlikely service coverage areas, sometimes crossing county lines. Although the borders of Lincoln County have remained stable, some of the communities within the county have merged. The merging of communities along with the change in diversity of telephone companies (also via merger) have possibly created for this research project an unavoidable methodological bias.

A portion of Lincoln County subscribers were found in the 1946 Corvallis telephone directory, including the communities Newport, Toledo, and waldport. I found no directory that could represent the east and north county for 1946. I instead used a 1951 telephone directory (Tri-County Telephone Company, Delake, Oregon) for North Lincoln county. This directory included the communities of otis, Neotsu, Wecoma, Oceanlake, Delake, Nelscott, Taft, Cutler City, Kernville and Vicinity. This directory, five years after the year 1946, was the closest directory in time to that year. It should be noted that a risk is taken here by using the 1951 directory due to the increase--12.6\%--of telephone service from 1946 to 1951 (Historical statistics of the United states 1976: 783). I decided, however, that the error from the increase of listings would be negligible compared to the error from leaving out a major region of the county. 
Due to the unavailabllity of the 1946 Multnomah County telephone directory (no directory could be found either through the telephone company, Historical society or the county library), the March 1947 directory was used. The term Multnomah County, however, may be misleading because the 1947 directory primarily focused on Portland. The official title of the directory was portland and vicinity Telephone Directory, March 1947. As the Portland (Multnomah County) 1947 directory and 1986 directories were categorized differently, it was necessary to include some areas that were technically not in Multnomah County. The 1986/1987 directory for the Portland area included Lake Oswego and Milwaukie. Lake Oswego and Milwaukie are not in Multnomah County. Due to the vast volume of listings, it was virtually impossible to separate these two communities from the tally for the 1986 year. To maintain continuity, the communities of Lake Oswego and Milwaukie were included in the tally for 1946. The 1947 directory had separated the communities so that Portland was identified as a separate community. Lake Oswego and Milwaukie were in this same directory, but under a separate section.

I estimated the proportion of listings for each directory. Each directory was formatted differently according to listings per page and column. Furthermore, the print size varied. Therefore, no standard could be used to estimate the listings for all of the directories. 
The number of listings in the directories per page were an average rather than an actual count. Using this average helped eliminate the impact of the business listings in the tallying. An average listing per page was estimated for each directory except 1946 Lincoln county: all of the listings for this county and year were actually counted and not estimated. TABLE II summarizes the total number of directory listings for each county and each year. This table demonstrates the exact methodology for each of the estimated 1 istings.

The estimated totals were used to represent the population from which the random component was chosen. As mentioned previously, a match of marital and population names was found: for the same time and place. After the matching was completed, tallies of these observed matches were entered into the statistical package systat (wilkinson $1988)$. 
TABLE II

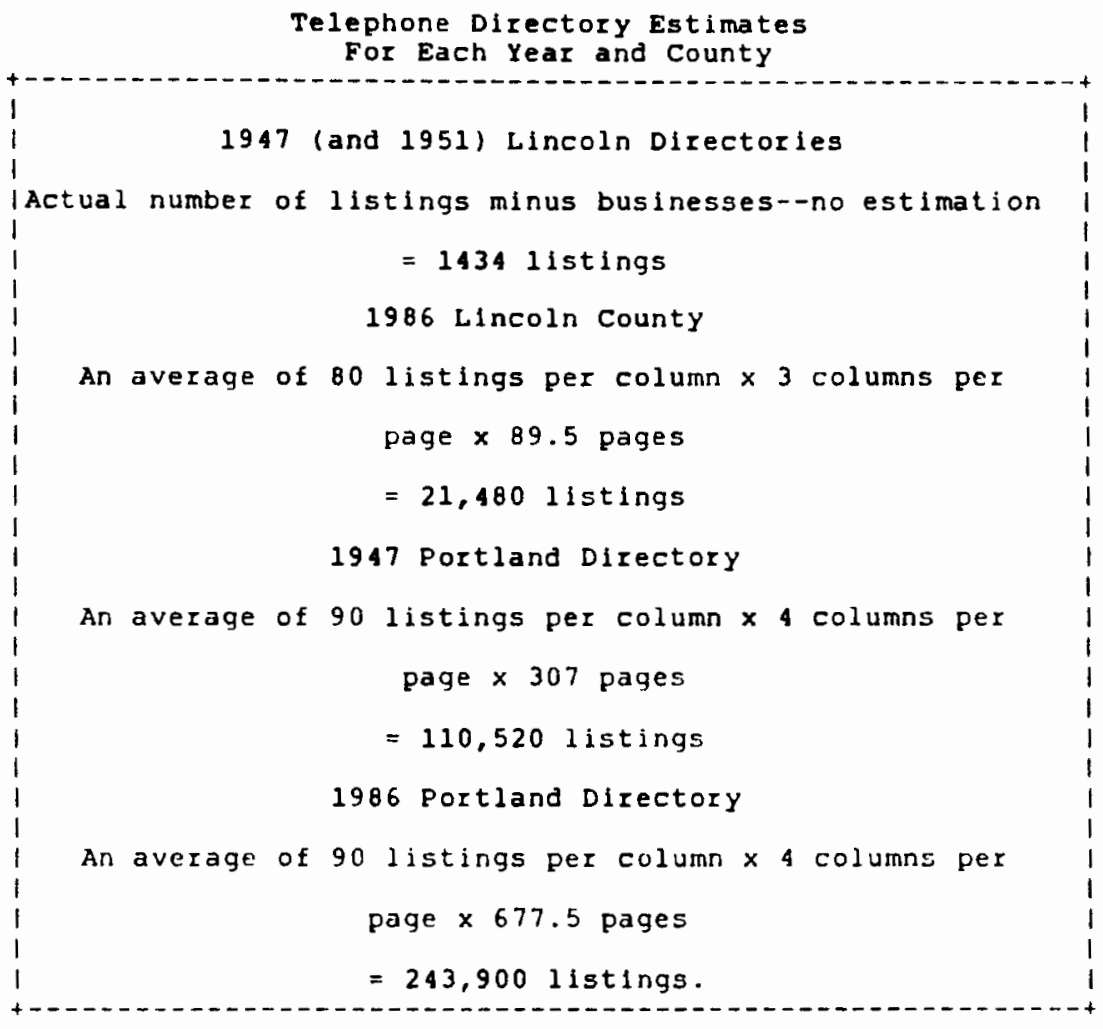




\section{CHAPTER IV}

\section{RESULTS}

Tables III through VI summarize the results of this research for both counties and years. Additionally, population and sample sizes are included for comparison.

\section{MARR I AGE RESULTS}

The number of marriages for Multnomah County for both years was relatively unchanged (see TABLE III). The 1946 population size for Multnomah County was 466,700 and for 1986 was 566,200 (Center for Population Research and Census): a net increase of 99,500. This increase in population is not reflected in the marriage records. In $1946,1.228$ of the Multnomah population chose to marry, in contrast to $0.97 \%$ of the population in 1986 who chose to marry.

The number of marriages for Lincoln County for the two study years were quite different: 170 for 1946 and 334 for 1986 (TABLE III). However, the population likewise grew in 1986. If one looks at the percentage of marriages relative to the population for that year it is seen that $0.89 \%$ of the population married in 1946 in Lincoln County and 0.918 of the population married for 1986 in Lincoln County. As seen by these percentages, this rural region has remained stable 
TABLE III

The Total Number of Marrlages, Sample sizes and Populations For Each Year and county

\begin{tabular}{lcccc} 
County & Year & $\begin{array}{c}\text { Number } \\
\text { OE Mariages }\end{array}$ & $\begin{array}{r}\text { Sample Population } \\
\text { S1ze }\end{array}$ \\
\hline Multnomah & 1946 & 5,714 & 667 & 466,700 \\
Multnomah & 1986 & 5,543 & 776 & 566,200 \\
Lincoln & 1946 & 170 & 84 & 19,100 \\
Lincoln & 1986 & 334 & 168 & 36,900 \\
\hline
\end{tabular}


with respect to marriage percentage in contrast to the urban region that has had a decline in marriages.

The decrease in relative number of marriages in Portland may skew the results of the mating patterns seen in the population. A bias may be present because the marriage records will not reflect those individuals who chose not to marry but cohabit, common law marriages, or those who chose to marry outside of the county. TABLE IV shows that the number of isonymous marriages was small for all populations. There were no isonymous marriages noted for Lincoln County in 1946. Two isonymous marriages were noted for both Lincoln County 1986 and Multnomah County 1986. There were 18 isonymous marriages noted in Multnomah County in 1946. TABLE IV also demonstrates that the number of observed isonymous marriages falls short of the expected number. This is particularly true in Multnomah county.

\section{INBREEDING COEFFICIENTS RESULTS}

Lincoln County 1986 showed the largest $F$ coefficient $(F=.001496)$ amongst all counties and years (TABLE $V)$. The random proportion of the F coefficient (Fr/F) was substantially smaller than the nonrandom (Fn/F) proportion: $5.74 \%$ and 94.328 respectively. The disparity between the two components indicates that relatedness in this population is primarily due to the effects of nonrandom mating. The 
TABLE IV

The Total Number of Expected

and Observed Isonymous Marrlages

\begin{tabular}{|c|c|c|c|c|c|}
\hline $\begin{array}{c}\text { Counties and } \\
\text { Years }\end{array}$ & & 1 & 1 & 0 & $\begin{array}{l}1 \\
1\end{array}$ \\
\hline $\begin{array}{l}\text { ILincoln County } \\
\text { ILIncoln County } \\
\text { i Multnomah County } \\
\text { I Multnomah county }\end{array}$ & $\begin{array}{l}1946 \\
1986 \\
1946 \\
1986\end{array}$ & $\begin{array}{l}1.5683 \\
15.366 \\
147.394 \\
178.468\end{array}$ & $\begin{array}{l}1 \\
1 \\
1 \\
1\end{array}$ & $\begin{array}{r}0 \\
2 \\
18 \\
2\end{array}$ & $\begin{array}{l}170 \\
1334 \\
15714 \\
15543\end{array}$ \\
\hline
\end{tabular}

Legend--

$E=$ expected number of isonymic marriages

$O=$ observed number of Isonymic marrlages

$U=$ unique names observed

$T=$ Total number of marrlages 
TABLE $V$

Isonymy coefficients for Lincoln and Multnomah Counties For both 1946 and 1986

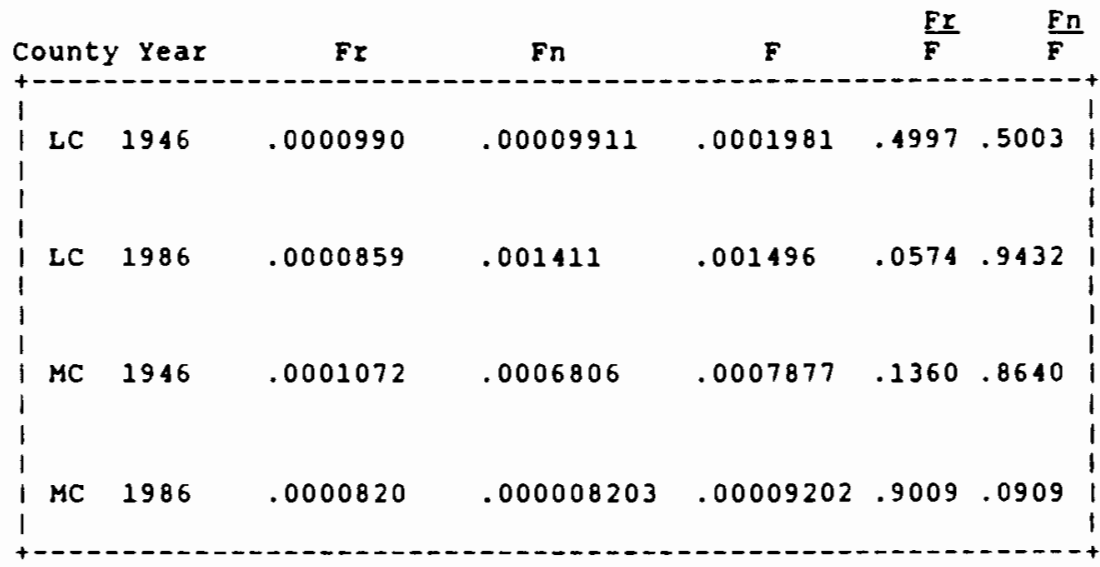


observed Fn was .001411, which was the largest nonrandom coefficient noted among all groups.

The second highest $F$ coefficient (.0007877) was noted in 1946 Multnomah County (TABLE V). The Fr/F and Fn/F ratios for Multnomah County 1946 are comparable to those found in

1986 Lincoln county: Fr/F was $13.60 \%$ and $F n / F$ was $86.40 \%$. Again as in Lincoln County 1986, it is the nonrandom component that dominates.

The isonymy coefficients were quite different. Lincoln County 1986 to Lincoln County 1946, The inbreeding coefficient $F$ was substantially smaller in 1946: .0001981 (TABLE $V$ ). Additionally it is interesting to note that the Fn in Lincoln County 1946 was substantially smaller than in Lincoln County 1986. The primary cause of the small fn in 1946 was the absence of isonymous marriages. Moreover, the random and nonrandom ratios in 1946 indicate that the inbreeding coefficient was equally influenced by both random and nonrandom phenomena: $F r / F=49.97 \%$ and $F n / F=50.038$. The inbreeding coefficient for Multnomah County 1986 (TABLE V) was the smallest $(F=.00009202)$. The random and the nonrandom component of the $F$ coefficient are the inverse of Lincoln County 1986. This especially can be seen via the ratios: $F r / F=90.09 \%$ and $F n / F=9.09 \%$. These results are compatible with the common expectation for a large Western 
society: a very large percentage of random mating and a very low percentage of nonrandom mating.

\section{SURNAMES}

TABLE VI summarizes the number of unique surnames and the percentage of unique surnames observed relative to the number of marriages for a given year and county. Lincoln County 1946 had the highest number of unique surnames (97.028) and the lowest number observed was in Multnomah County 1946 with 74.968 .

This information tends to defy common expectations for these two populations. However, according to the $F$ coefficients of these counties, the percentage of unique surnames appears to be reasonable. That is, a smaller F coefficient should correspond to a higher percentage of unique surnames. 
TABLE VI

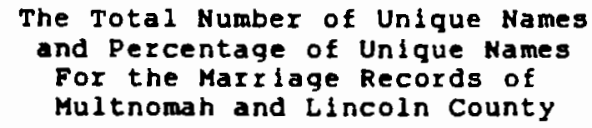

\begin{tabular}{lccc} 
County & Year & $\begin{array}{l}\text { Unique } \\
\text { Surnames }\end{array}$ & $\begin{array}{c}\text { Percentage of } \\
\text { Unique Surnames }\end{array}$ \\
\hline Lincoln & 1986 & 298 & 88.69 \\
Multnomah & 1946 & 1000 & 74.96 \\
Lincoln & 1946 & 163 & 97.02 \\
Multnomah & 1986 & 1245 & 80.21 \\
\hline
\end{tabular}

Percentage of Unique surnames=

Number of Unique Surnames Noted in the Sample of Marriage Rec

Total Number of Sampled Marriages for a spectfic Year and Cty 


\section{CHAPTER V}

\section{DISCUSSION AND CONCLUSIONS}

Before discussing this research project, a brief historical overview of the year 1946 is in order. This year in particular is important because of the mobility of the populations in response to the ending of the war. The year 1946 was a period of resettlement for this nation as well as other nations. The war era led to a tremendous amount of population movement. This movement included not only groups moving within the United states to support military causes but also Europeans and other immigrants escaping to safer turf. In 1946 the total immigration into the United states was 108,721 (Historical Statistics of the United States 1960: 62) of which half were Europeans. This was a sharp increase in comparison to 1941-1945, which averaged 34,190.

The Multnomah County area was not exempt from this large population movement. MacColl (1979) noted that from 1940 to 1946 the population of Portland had increased by 35 percent. According to the Oregon Blue Book (1957-1958), the population in 1940 was 355,099 and in 1950 was 471,537 .

In 1942 the Portland area became alive with the building of Vanport City. The primary reason for its creation was to support the United States' war effort. 
Vanport received national acclaim as being the largest housing project and one of the few major shipbuilding centers in the United States (Maben 1987). In order to support this effort, labor was desperately needed and laborers were imported from all areas of the United states. In fact, Maben noted that within one year after the declaration of war the region had increased by 160,000 new workers (1987). Maben (1987) notes that many families came to Oregon from the South, the Midwest, and New York City. Maben wrote of one such family who came in stages to Oregon. Eventually they numbered 25 family members. Maben also noted that oregon's black community increased by 800 percent from 1940 to 1946 (Maben 1987).

Three assumptions formed the foundations of this study. Additionally, I noted that these assumptions are only partially satisfied. It is important to emphasize that it is difficult to determine the origin of surnames in the populations that I have studied. One recalls that surnames are to be monophyletic rather than polyphyletic. Secondly, names are to be passed along via the male line and, thirdly that migration is equal between the two sexes.

The original hypotheses of this research were that I would find more relatedness in Lincoln county than in Multnomah County both for years 1946 and 1986. Secondly, I would discover more relatedness in Multnomah County for 1946 
than in 1986. The data partly confirms these hypotheses, however, there were unexpected results.

I predicted that Lincoln County 1946 would have the highest inbreeding coefficient. As the results show lincoln County 1986 had highest coefficient, followed by Multnomah County 1946 and then finally Lincoln County 1946.

Several factors may have contributed Lincoln County's low inbreeding coefficient. First, there may have been a decrease of mates available. This decline may have been directly influenced by the war time period wherein many individuals were still possibly coming home from wartime assignments or still employed in a war support role. Secondly, social pressures, such as incest taboos, may have been strong enough to prevent intermarrying among close relatives. The combination of fewer available mates and/or social pressures may have necessitated exogamy. Thirdly, the community may have had significant numbers of migrants (both emigrants and immigrants) because of the coastal nature of much of the county. Immigrants into the county may have been seeking employment from the fish industry. Those individuals who immigrated out of the county may have been seeking better or different employment than what was available in the county. The movement of individuals into and out of the county may explain the small inbreeding coefficient. The high percentage of unique surnames 197.028 of observed names were unique) could represent a high degree 
of population heterogeneity as evidenced by the small amount of relatedness ( $F=.0001981)$ observed in the population.

The 1986 inbreeding values obtained from Lincoln County may more accurately represent the population mating patterns than in 1946. To reiterate, 1946 was a time of population resettlement: the populations that had moved so much due to the war were now shifting again. By 1986 the community had grown substantially from 19,100 to 36,900 . Although the size had increased, the inbreeding coefficient was larger than in 1946, suggesting that there was more relatedness in the population in 1986. One explanation for the disparity may be that the community experienced less migration. A second explanation may be that intermarrying among close relatives may have been more socially acceptable in 1986 than in Lincoln county 1946. A third reason may be that due to the increase in population size and peace time conditions it was not as necessary to go outside the community for mates.

One factor must be considered when discussing both studied years for Lincoln county is the small number of isonymous marriages observed. Lasker (Lasker et al. 1987 and Lasker 1988 ) notes that marital isonymy is usually a rare event and that the sampling error can be quite high due to the small sample size. As noted by Lasker (personal communication) the inbreeding coefficient is a statistical estimate. This estimate represents a sample of marriages 
from all descent 1 ines, thus it can make the statistical error of the isonymy inbreeding coefficient very large. It should be noted, however, that the random inbreeding coefficient is not affected by this phenomenon. Furthermore, the results obtained in this study are compared in a relative manner making the analysis of the coefficients equal.

The reason that the Multnomah County 1946 inbreeding coefficient is the second highest amongst the four groups may be directly linked to migration. As mentioned in the brief historical review, Multnomah County was subject to a tremendous population increase during World War II.

However, there was also an earlier migration into the state which totaled 175,000 during the years of 1929-1940 (MacColl 1979: 524). These immigrants primarily came from the North and South Great Plains, North Central U.S and California (MacColl 1979: 524). The combination of these two waves of immigration may have singly or in concert affected the 1946 Multnomah county $F$ coefficient, as will be shown below.

According to MacColl (1979: 575) during the first few years of World War II, over 72,000 migrants workers came to portland to seek employment. This in part would include the immigration of the large families during the early 1940's into Vanport City. Though perhaps many families eventually returned to their native states, it can be assumed that many stayed as well. 
Such massive migration in such a short period undoubtedly influenced the social environment of portland residents. It can be argued for example that the migrants and local residents remained isolated from one another. As one will recall, the Fn/F for Multnomah County 1946 was $86.40 \%$, meaning that $86.40 \%$ of the inbreeding coefficient was due to the effects of nonrandom mating. Isolated population pockets would increase this nonrandomness.

Lastly, the results noted from Multnomah County 1986 were expected. The exceedingly small inbreeding coefficients were anticipated before the onset of this research project. The low percentage $(80.21 \%)$ of unique surnames, however, makes one speculate that the inbreeding coefficient should have been larger. One should, however, be reminded that the $F$ and $F$ are greatly influenced by the presence or absence of marital isonymy. The low inbreeding coefficient observed in this county and year, therefore, was very sensitive to the very low frequency of isonymous marriages .

At this point two other inbreeding coefficients need to be mentioned. I did not use these for comparison because of methodological disparities or uncertainity in the data. As I mentioned earlier, it was difficult at times to determine from the marriage records if an isonymic marriage had actually occurred. The three catagories of same surname marriages not considered 1sonymic were: remarriages; Aslan 
marriages; and suspected cases of brides applying under the groom's surname rather than her maiden name. This particularly was true of the 1946 Multnomah County marriage applications. If, however, relatedness could have been validated, the number of isonymous marriages would have increased from 18 to 26 . This increase would also have increased the F coefficient (from .0007877 to .001138), making it comparable to Lincoln county 1986.

The second inbreeding coefficient not discussed was taken from Multnomah County 1986. Because of methodological disparities, I could not use this information to compare with the other three strata. The 1986 marriage applications were the most complete of all records. These records documented the father's surname and the mother's maiden name. In the course of this investigation I found 13 couples whose parents shared the same surname in one form or another. For example, the bride's mother's maiden name (Smith) was the same as the groom's mother's maiden name (Smith). Taking this into account, one finds that the inbreeding coefficient increases substantially from .00009202 to .0006781 .

If one were to take these inbreeding coefficients into account, one would note that there is a closer relatedness within each population. The change in results from the more complete Multnomah county 1986 records does change the overall picture of relatedness between the four strata under 
study. However, there is nothing in this unavoidable methodologic flaw to suggest that there may have been more instances of maternal maiden name relatedness in Lincoln County.

As noted in the methods section, the Multnomah county marriage license bureau included all applications in their final tally per given year. This factor biases the results in this county. The percent of isonymous marriages, $P$ was based on the total number of isonymous couples relative to the total number of marriages. This calculated $P$ value is part of the Fn and the $F$ coefficients. Thus, if the number of actual marriages is less (making the numerator of the equation Fn smaller), the Fn and $F$ coefficients will be smaller. This observation would indicate that more relatedness is probable for both years in Multnomah County than has been revealed by the present results.

In an effort to validate and/or compare my data, I compared them with several other isonymy studies (TABLE VII). The comparisons listed primarily focus on population sizes from 35,000 to 60,000 . The inbreeding coefficients vary from .00307 to to .000912 . As TABLE VII shows, there is considerable varlation in time depth for these populations. One isonymy study done on the Tasmanian population for the period 1896-1899 yielded results comparable to my study done of Lincoln county 1986. The population size of Region 10 in Tasmania was 36,604 , which is of comparable size to Lincoln 


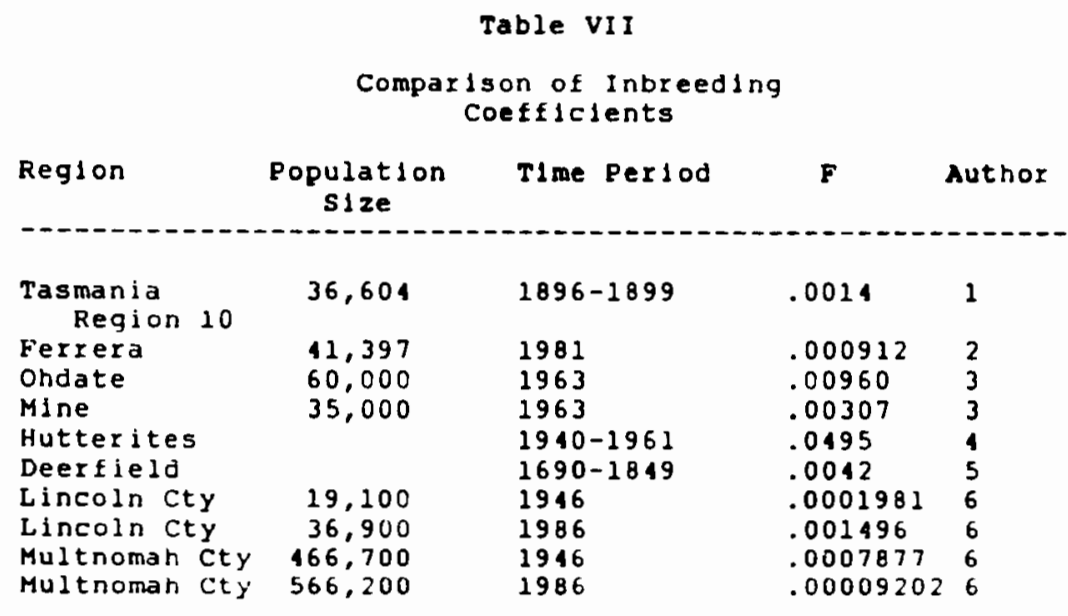

1-Lafranchi et al (1988), 2-Barral et al (1987), 3-Yasuda and Furusho (1971), 4-Crow and Mange (1965), 5-swedlund and Boyce (1983), 6-Michalczyk (1989) 
County 1986 of 36,900 . This area is an urban region which lies close to the southeastern coast. The number of isonymous marriages was 6 out of a total of 1102 , or $.54 \%$. The F coefficient was .0014 , of which Fn was .0010 , the Fr was.0003 and the Fn/F ratio was .77 (Lafranchi 1988).

This contrasts with Lincoln County 1986 where the number of isonymous marriages was 2 out of a total of 334 , or . 598 of the total marriages were isonymous. The F coefficient was .001496 , the Fn was .001411, the Fr was .0000859 and the Fn/F ratio was .9432 .

Although the inbreeding coefficients are similar, the nonrandom and random components differ. A greater portion of nonrandomness is seen in Lincoln county than in Region 10, Tasmania, a difference of $17 \%$ between the two Fn/F ratios. The differences seen may be a function of sample size: Lincoln County 1986 had 168 marriages and the Tasmania study had 1102. The percentages of isonymous marriages observed in Lincoln County and Tasmania were based on the number of isonymous marriages compared to the total marriages for each region. Despite the disparities noted between the two communities, it is interesting that similarities are also evident and it appears that using isonymy analysis for comparison can provide the researcher with a tool to estimate and evaluate population relatedness. The present study motivates one important question: to what extent do individuals from a large population behave in 
the same fashion as do individuals of a small population. That is, if small population inbreeding coefficients are relatively small then may one assume that exogamy is operative? If this is the case, then what average distance is involved for exogamous relationships? Moreover, how would this distance compare with subgroups in a large population? Or, what average distance is noted among mates in a large population? To verify this, a further investigation of marital distances needs to be done. This is especially important because of the increased inbreeding coefficient seen in Multnomah County 1986 when parental surnames were compared.

More investigation of the present data is necessary and may include such studies as marital distances, repeated pairs measurement (Lasker 1988), and relatedness measurements between the two populations.

In summary, the use of isonymy analysis has brought up many important and interesting factors regarding the populations found in oregon. Furthermore, it has illuminated the population relatedness of a large group at two periods in time. Although there are still many variables that cannot be controlled for, it appears by comparison that the results found within both populations are reasonable. 


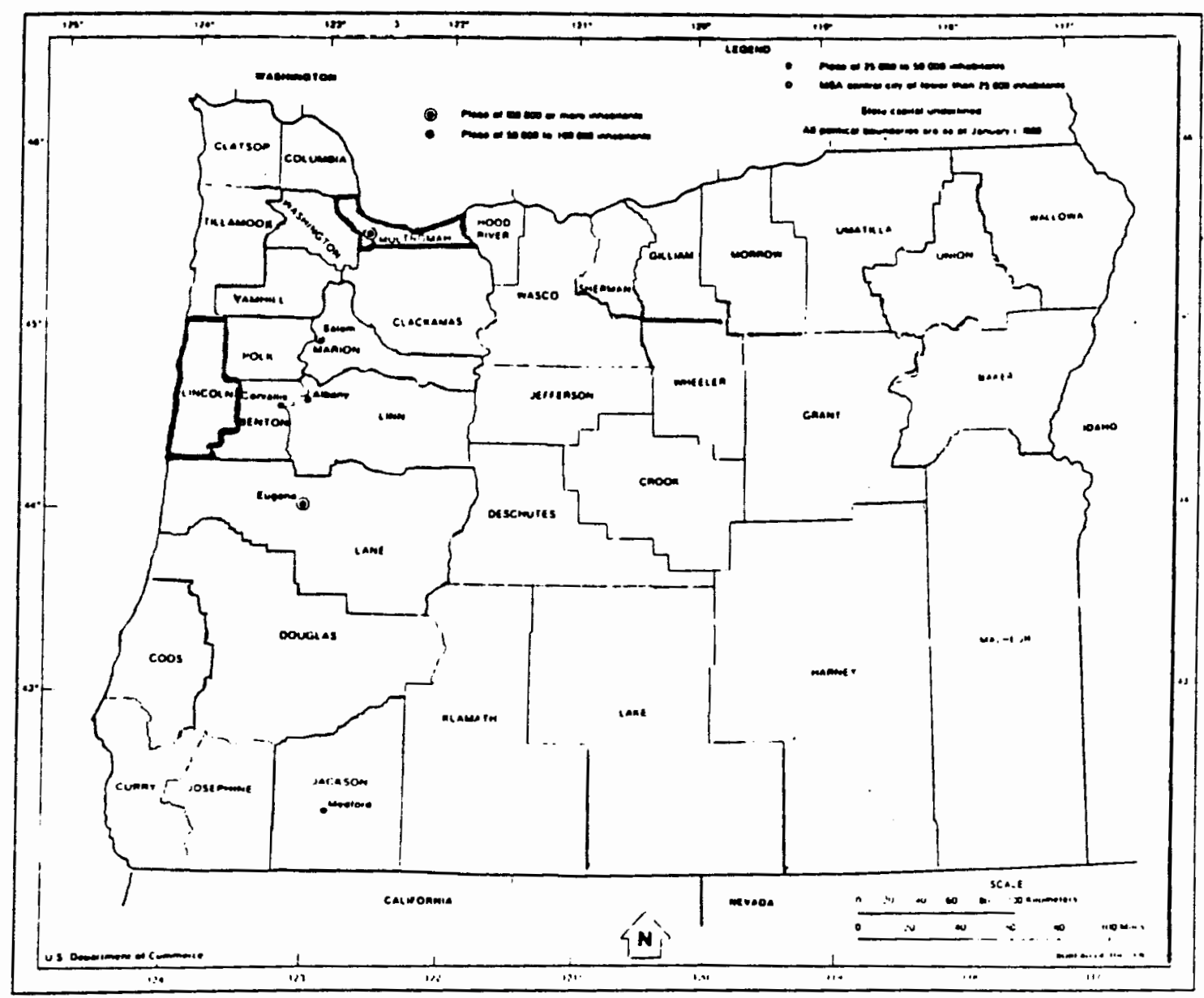

Fizure 1. Map ui Oregon--ilultnomah and Incoin Counties. 


\section{REFERENCES CITED}

Allen, G. (1988) Random Genetic Drift Inferred from Surnames in old Colony Mennonites. Human Biology, 60, 4, 639653 .

Arkin, H. (1974) Handbook of Sampling for Auditing and Accounting. McGraw-Hill Book Company.

Barrai, I., Barbujani, G., Beretta, M., Maestri, I., Russo, A. (1987) Surnames in Ferrara: distribution, isonymy and levels of inbreeding. Annals of Human Biology, 14, $5,415-423$.

Conley, N. Personal communication November 1988.

Clegg, E.J. (1986) The use of parental isonymy in inbreeding in two outer Hebridean populations. Annals of Human Biology, 13, 3, 211-224.

Crow, J.F. and Mange, A.P. (1965) Measurment of inbreeding from the frequency of marriages between persons of the same surname. Eugenics Quarterly, 12, 199-203.

Crow, J.F. (1983) Discussion. In: surnames as markers of inbreeding and migration (arranged by $K$. Gottlieb). Human Biology, 55, 383-97.

Darwin, G.H. (1875) Marriages between first cousins in England and their effects. Journal of the statistical Society. 38, 153-84. (Cited after Lasker, 1985; Crow, 1983 ; and Yasuda, 1983.)

Fuster, V. (1986) Relationship by Isonymy and Migration Pattern in Northwest spain. Human Biology, 58, 3, 391406 .

Gottlieb, K. (1983) Genetic Demography of Denver, Colorado: Spanish Surname as a Marker of Mexican Ancestry. Human Biology, 55, 2, 227-234.

Hurd, J.P. (1983) Comparison of Isonymy and Pedigree Analys is Measures in Estimating Relationships between three "Nebraska" Amish Churches in Central

Pennsylvania. Human Blology, 55, 2, 349-355. 
Jorde, L.B. and Morgan, K. (1987) Genetic Structure of the Utah Mormons: Isonymy Analysis. American Journal of Physical Anthroplogy, 72, 403-412.

Kamizaki, M. (1954) Frequency of isonymous marriages. Seibutsu Toei-gaku Zassi, 2, 292-98. (In Japanese. Cited after Yasuda, 1983.)

Lafranchi, M., Mitchel1, R.J., and Kosten, M. (1988) Mating structure, isonymy and social class in late nineteenth century Tasmania. Annals of Human Biology, 15, 5, 325336 .

Lasker, G. (1968) The occurence of identical (isonymous) surnames in various relationship in pedigrees: a preliminary analysis of the relation of surname combinations in inbreeding. American Journal of Human Genetics, 20, 250-257.

Lasker, G. (1969) Isonymy (occurrence of the same surname in affinal relatives): a comparison of rates calculated from pedigrees, grave markers and death and birth registers. Human Blology, 41, 309-21.

Lasker, G. (1977) A coefficient of relationship by isonymy: A method for estimating the genetic relationshp between populations. Human Biology, 49, 489-93.

Lasker, G. (1978 a) Relationships among the otmoor villages and surrounding communities as inferred from surnames contained in the current register of electors. Annals of Human Blology, 5, 105-11.

Lasker, G. (1978 b) Increments through migration to the coefficient of relationshp between communities by is onymy. Human Biology, 50, 235-40.

Lasker, G. (1983) The frequencies of surnames in England and wales. Human Biology, 55, 331-40.

Lasker, G (1985) Surnames and Genetic structure, Cambridge University Press.

Lasker, G. (1988) Repeated Surnames in Those Marrying into British One-surname "Lineages" : An Approach to the Evaluation of Population structure through Analysis of the Surnames in Marriages. Human Biology, 60, 1, 1-9.

Lasker, G. (1989) Personal communication 26 February 1989. 
Lasker, G., Chlarell1, B., Masal1, M., Fedele, F. and Kaplan, B. (1972) Degree of human genetic isolation measured by isonymy and marital distances in two communities in an Italian Alpine valley. Human B10logy, 44, 351-60.

Lasker, G., Coleman, D., Aldridge, N. and Fox, w. (1979) Ancestral relationships within and between districts in the region of Reading, England, as estimated by isonymy. Human Blology, 51, 445-60.

Lasker, G. and Kaplan, B. (1983) English place-name surnames tend to cluster near the place named. Names, 31, 167177. (Cited in Lasker, 1985.)

Lasker, G. and Roberts, D. (1982) secular trends in relationship as estimated by surnames: a study of Tyneside parish. Annals of Human Blology, 9, 299-307.

Lasker, G., Mascle-Taylor, G., and Coleman,D. (1986) Repeating Pairs of Surnames in Marriages in Reading (England) and Their signiflcance for Population structure. Human Biology, 58, 421-425.

Maben, M. (1987) Vanport, Oregon Historical Society Press.

MacCol1, E.K. (1979) The Growth of a City Power and Politics in Portland, Oregon 1915-1950, The Georgian Press Press Company.

Mascie-Taylor, C.G.N., Lasker, G.W., Boyce, A.J. (1987)

Repetition of the Same surnames in Different Marriages as an Indication of the structure of the Population of Sanday Island, Orkney Islands. Human Blology, 59, 1, 97-102.

McArthur, L.A. (1982) Oregon Geographic Names. The Press of the oregon Historical soclety.

Official Population Estimates for Oregon Counties and cities. Center for Population Research and Census, School of Urban and Public Affairs, Portland state University January 1988 and personal communication with Census offlce.

Oregon Blue Book 1957-58. Edited by Schenk, H.S.

Relethford, J.H. and Jaguish, C.E. (1988) Isonymy, Inbreeding, and Demographic Variation in Historical Massachusetts. American Journal of Physical Anthropology, 77, 243-252. 
Smith, M.T. and Hudson, B.L. (1984) Isonymic relationships in the parish of Fylingdales, North Yorkshire, in 1851. Annals of Human Biology, 11, 2, 141-148.

Swedlund, A.C. and Boyce, A.J. (1983) Mating structure in historical populations: Estmation by analysis of surnames. Human Blology, 55, 2, 251-262.

U.S Department of Commerce, Bureau of the Census, Historical statistics of the United States: Colonial Times to 1970, 108th Edition 1988 .

U.S. Department of Commerce, Bureau of the Census, Historical statistics of the United States: Colonial Times to $1957,1960$.

Weiss, K. , Chakraborty, R., Buchanan, A. and Schwartz, R. (1983) Mutations in names: implications for assessing identity by descent from historical records. Human Biology, 55, 313-22.

Yasuda, N. (1983) studies of isonymy and inbreeding in Japan. Human Biology, 55, 263-76.

Yasuda, N. and Furusho, T. (1971) Random and Nonrandom Inbreeding Revealed from Isonymy study. I. Small cities of Japan. American Journal of Human Genetics, 23, 303316 .

Yasuda, N. and Morton, N. (1967) studies in human population structure. In Proceedings of the Third International Congress of Human Genetics, 23, 303-16. (Cited after Roberts and Roberts 1983.)

Yasuda, N. and Furusho, T. (1971) Random and Nonrandom Inbreeding Revealed from Isonymy study. I. Small Cities of Japan. American Journal of Human Genetics, $23,303-316$. 